【論 文】

\title{
市町村主導による鳥獣害対策の現状と農家の対策評価
}

\author{
長門雄治* ・吉仲怜** \\ (*岩手大学大学院連合農学研究科. ** * 弘前大学農学生命科学部)
}

\section{The current condition of municipality measures against wildlife damage and farmers' evaluation.}

\begin{abstract}
Yuzi NAGATO (United Graduate School of Agricultural Sciences, Iwate University) Satoshi YOSHINAKA (Hirosaki University)
\end{abstract}

This paper clarified following two points. Firstly, present situation of against the wildlife damage measures that administration adopted. Secondly, analyzed the farmers' evaluation of measures through questionnaire survey.

Firstly, in Nishimeya Village, Aomori Prefecture, farmers had different understanding about the current measures. It was assumed that the information of the measures had not been used commonly by majority farmers.

Secondly, in evaluating the efficiency of the measures, some farmers pointed out that they

\section{1.はじめに}

野生動物による農作物被害を代表とする鳥獣害 が社会化し，特に中山間地農業においては深刻な 問題となっている。鳥獣害問題の深刻化を受け， 2008年「鳥獣による農林水産業等に係る被害の防 止のための特別措置に関する法律」（以下，鳥獣 被害防止特措法とする）が施行された。鳥獣被害 防止特措法は，鳥獣害防止を主目的とする初めて の国法であり，その特徴は市町村を対策の担い手 としている点である。市町村による鳥獣害対策は were not practicing the measures; moreover, they complained that some request for support from the village had not been admitted.

Thirdly, about raising the efficiency of the measures, such as through building electric fence and relative maintenance, the participating degree from aged farmers was low. The current fact is, farmers have to pay for the erection expense. Therefore, it is also consumed that, fearing the burden, even though some aged farmers wish to participate; they would not have the ability to afford the expense.

有識者の意見などを参考にしているものの，農家 を代表とする「利害関係者」の意見を吸収する弾 力性を持っている，すなわち，農家の意見が対策 に大きく影響を与える可能性を有している.

実際には本法制定以前より，被害農家の要望を 踏まえながら，市町村では各種の対策を採ってい る、今後は法制定による更なる手厚い助成も期待 される.このように，鳥獣害対策の気運が高まる 中で，今後の対策の実効性を高める上でも，これ までの市町村の施策を評価する必要がある. 
これまでの鳥獣害研究は, 生態学などを活用し た防除策の検討など, いわゆる野生動物側の研究 が多い。これに対し，室山[3]，鈴木[6]らは，野生 動物の研究に加え, 被害者である人間及びその活 動に関する研究の必要性を説いている。しかし， このような人間側の研究は十分とはいえず，その 中でも，対策主体としての市町村を対象にし，農 家による対策への評価に注目した研究はみられな い.

本論文の課題は, 青森県西目屋村を事例に, 市 町村主導による鳥獣害対策の展開を整理し, 農家 アンケートより，これまで採られた対策の評価を 明らかにすることである. その上で，今後の対策 の方向性を考察する。

\section{2.鳥獣害の推移及び鳥獸被害防止特措法の施行}

鳥獣害の推移を把握する上で, 図 1 から被害額 の推移をみていく，まず，全国の動向をみていく と，6年間においては2004年が最も高く，約206 億円となっており，全体的には200億円前後を推 移している. 加害動物は, シカとイノシシの被害 が最も多く，次いでサルとなっている。一方で, 東北をみていくと全体で15億円から20億円とな っており，山形県が最も多く10億円前後となって おり，調查地である青森県は，1.5億円前後となっ ている。

深刻化する被害を背景に，鳥獣被害防止特措法

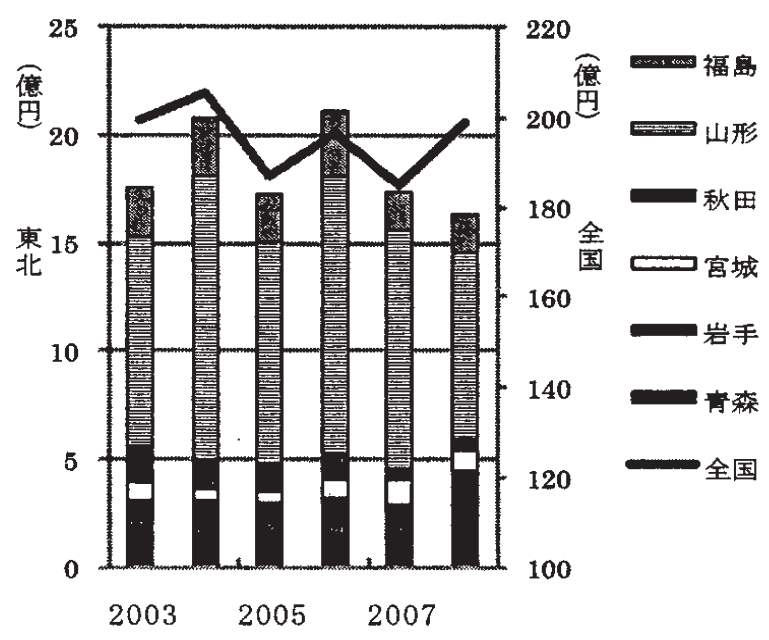

(年)

図 1 全国東北各県の被害額推移

資料：農林水産省「全国の野生鳥獣類に上る農作物 被害状況について」各年度より筆者が作成。
が2008年に施行された。鳥獣被害防止特措法の中 心ともいえるのが，「被害防止計画」の作成であ る、「被害防止計画」は，文字通り鳥獣害対策の 計画が示されたものであるが，この計画は市町村 が作成することとなっている．市町村が「被害防 止計画」を作成することで，財政面の措置や駆除 権限委譲などの優遇策がとられている。また，「鳥 獣被害防止総合対策交付金」においても「被害防 止計画」が推進されている。すなわち，鳥獣害対 策の要, 地域の鳥獣害対策の先導的役割が市町村 に期待されている。

\section{3、西目屋村主導の鳥獸害対策の推移}

調查地である青森県西目屋村は，世界遺産白神 山地を有する山閒農業地带である，鳥獣害が早く から確認され，対策についても比較的早くから取 り組んできた。対策の実施主体となってきたのは, 村である。鳥獣被害防止特措法に基づき，「対策 協議会」を設置し，「被害防止計画」を作成して いる.

図 2 は, 西目屋村の被害額の推移及び村で行っ てきた対策の推移を示したものである，村主導で 行ってきた対策として，過去に 3 対策，現在は 5 対策が行われている。過去の対策として，「七面 鳥のヒナ助成」は，七面鳥の鳴き声に野生動物の 忌避効果がある, としてヒナの購入助成を行った. また，「ボランティアによる追い払い」は，N A

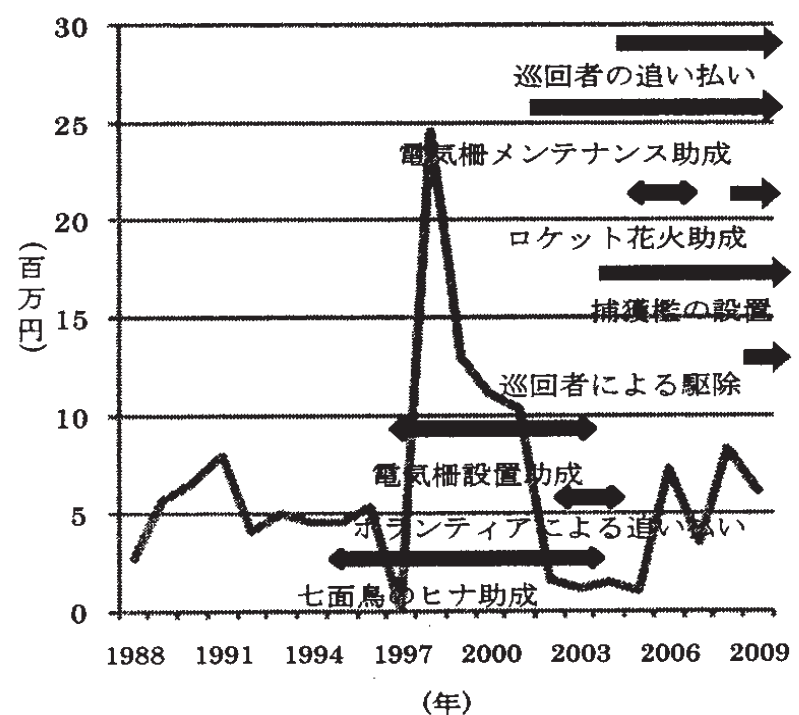

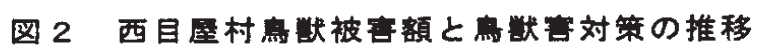
资料：西目屋村资料より筆者が作成. 
P 1)(西目屋アニマルパトロール) という活動で, いわゆるグリーンツーリズムの一環として，農作 業体験の他に野生動物の追い払いを行う，という ものである。「電気柵の設置助成」は，村費，県 費, 国費から電気柵を設置する際の材料費を助成 するというものである，次に，現行対策の「巡回 者の追い払い」は，村で「巡回者」を雇い，住民

（農家）から野生動物の目撃情報が寄せられた場 合，現地に赴き追い払いをする，というものであ る.また，「巡回者による駆除」は，巡回者が村 からの依頼を受けて，駆除を行う，というもので ある。「捕獲檻の設置」は, 村で捕獲檻を設置し, 捕獲した野生動物に対して，マーキング及び駆除 を行うというものである。「ロケット花火助成」 は，追い払いの際に用いるロケット花火の購入助 成である。「電気相メンテナンス助成」は，先の 電気柵についてメンテナンスを行う際，材料費の 助成を行う，というものである.

被害金額の推移をみていくと, 1992年から1996 年までは500万円前後で推移している．1997年に 大幅に減少するも，1998年には約2500万円に上っ ている．2000年，2001年共に1000万円を超える 金額で推移しており，2002年から2005年にかけて は低い金額となっており，2006年に上昇，2007 年に減少，2008年に再び上昇している。

\section{4. 対策への農家の評価}

\section{1) アンケート調查概要}

ここからは，先に示した村主導で行ってきた鳥 獣害対策を中心に，対策についての農家評価を， アンケート調查及び聞き取り調查を基に述べてい $<$.

アンケート調査は 2009 年 12 月から 2010 年 1 月 に行い, 西目屋村の「被害調查」と共同で行った。 対象は全農家とし，配布戸数は183戸，回答数は 51戸（回答率：27.9\%）である.

表 1，2は，アンケートの回答者の年齢と農家 区分の割合を西目屋村全体の割合と比較したもの である。これをみていくと，年齢構成，農家区分 ともに西目屋村全体の数字と同様の割合を示して いることが分かる．また，回答数が51と少ないの は，先に示したように西目屋村の「被害調查」と
表 1 西目屋村農家及び アンケート回収者の年龄構成

\begin{tabular}{c|r|r|r|r}
\hline & $\begin{array}{c}\text { 西目屋村 } \\
\text { (人) }\end{array}$ & $\begin{array}{c}\text { 割合 } \\
(\%)\end{array}$ & $\begin{array}{c}\text { 回答者 } \\
\text { (人) }\end{array}$ & $\begin{array}{c}\text { 割合 } \\
(\%)\end{array}$ \\
\hline$\sim 40$ 代 & 27 & $14.8 \%$ & 8 & $15.7 \%$ \\
\hline 50 代 & 55 & $30.2 \%$ & 15 & $29.4 \%$ \\
\hline 60 代 & 49 & $26.9 \%$ & 13 & $25.5 \%$ \\
\hline 70 代 & 51 & $28.0 \%$ & 15 & $29.4 \%$ \\
\hline 計 & 182 & $100.0 \%$ & 51 & $100.0 \%$ \\
\hline
\end{tabular}

資料：アンケート及び2005年農林業センサス

「農業経営体数」より筆者が作成。

表 2 西目屋村晨家及び アンケート回収者の農家区分

\begin{tabular}{l|r|c|r|c}
\hline & $\begin{array}{c}\text { 西目屋村 } \\
(\text { 戸) }\end{array}$ & $\begin{array}{c}\text { 割合 } \\
(\%)\end{array}$ & $\begin{array}{c}\text { 回答者 } \\
(\Lambda)\end{array}$ & $\begin{array}{c}\text { 割合 } \\
(\%)\end{array}$ \\
\hline 農家戸数 & 182 & - & 51 & - \\
\hline 専業農家 & 33 & $18.1 \%$ & 8 & $15.7 \%$ \\
\hline 兼業農家 & 149 & $81.9 \%$ & 40 & $78.4 \%$ \\
\hline 第1種兼業農家 & 39 & $21.4 \%$ & 16 & $31.4 \%$ \\
\hline 第2 種兼業農家 & 110 & $60.4 \%$ & 24 & $47.1 \%$ \\
\hline 未回答 & - & - & 3 & $5.9 \%$ \\
\hline
\end{tabular}

資料：アンケート及び2005年農林業センサスより

筆者が作成。

同時に行ったため，鳥獣害がなかった農家から回 答が得られなかったためである，そのため, 回答 は被害農家に偏っていると推察される。

表 3 は，対策への農家の評価を示したものであ る. 項目は, 先に示した村主導の現行対策及び過 去に行った対策，個人等で行っている対策とし， それぞれの対策について，認知度（対策を知って いるかどうか），参加度（参加の有無），有効性

(対策が有効であるかどうか)，実施主体（どの 実施主体が対策を行うべきか），実施度（十分実 施されているかどうか）の5つの設問で各農家の 評価をみた。なお各設問の詳細についても表 3 に 示した。

\section{2) 評価の概要}

評価の概要を述べる上で，設問毎に評価をみて いく，認知度については，村が主導で行っている 現行の対策が高い数值を示していることが分かる. すべての対策において $85 \%$ 以上が「知っている」 と回答している。これに対し，過去の対策及び個 人等で行う対策については，認知度が低い数值を 示している. 次に，参加度2）についてであるが，

「行っている（参加している，参加したことがあ る)」と回答した割合が全体的に低く，認知度の 高い村主導の現行对策においては，対策により大 


\section{表 3 西目屋村鳥獣害対策の農家評価}

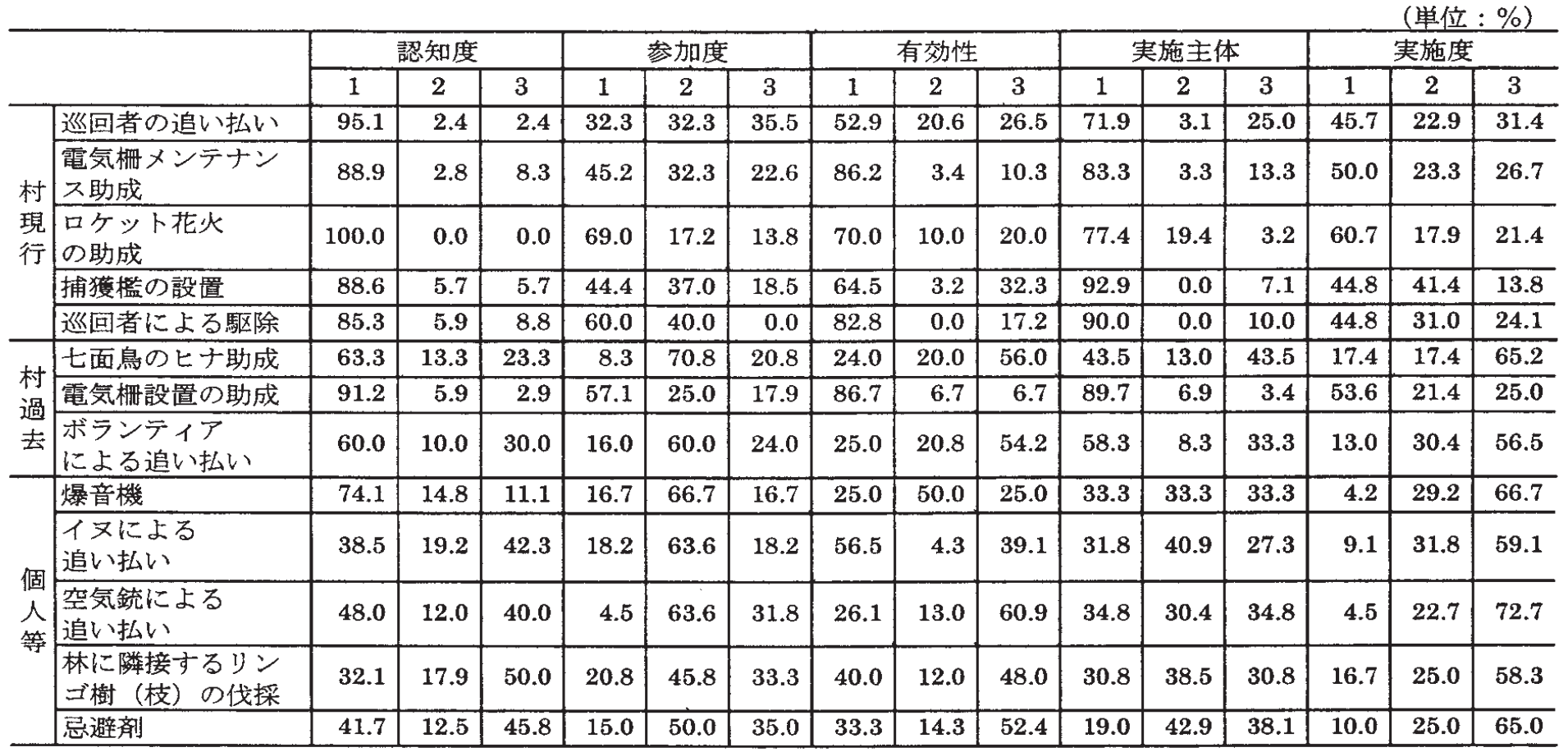

資料 : アンケートより筆者が作成.

注 : 各設問の回答は以下の通りである.

認知度： 1 ‥知っている $2 \cdots$ 聞いたことがある $3 \cdots$ 知らない

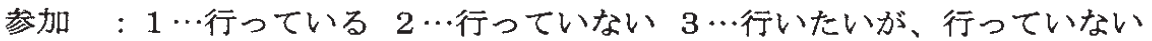

有効性： 1 ‥有効である $2 \cdots$ 有効でない $3 \cdots$ 分からない

主体：1 ‥村が行うべきだ $2 \cdots$ 個人が行うべきだ $3 \cdots$ 分からない

実施度： $1 \cdots+$ 分実施している $2 \cdots+$ 分実施していない $3 \cdots$ 分からない

きな開きがみられる。一番值が高い「ロケット花 火の助成」と一番低い「巡回者による追い払い」 は，40\%程開きがある。加えて，「行いたいが， 行っていない」といら回答は，「空気銃による追 い払い」，「林に隣接するリンゴ樹（枝）の伐採」,

「忌避剤」の個人等で行っている対策（村主導で 行っていない対策）が高い数值を示しているが， 村主導の現行対策においても「巡回者による追い 払い」は，高い数值を示している. 次に有効性に ついてであるが,村主導の現行対策については有 効である」との回答が，高い数字を示している.

「巡回者による駆除」は $80 \%$ 超え，「電気栅」 については，現行対策の「電気梱のメンテナンス 助成」，過去対策の「電気柵設置の助成」共に $85 \%$ を超えている。また，個人等の対策において「犬 による追い払い」，「林に隣接するリンゴ樹（枝） の伐採」が比較的高い数值を示している，実施主 体については, 村主尊の現行対策及び過去対策に ついては，「村が行うべきだ」との回答が多い一 方で，個人等で行っている対策においては，「個
人が行うべきだ」との回答が最も多い割合を示し ているが，「村が行うべきだ」との回答も3割程 ある。最後に実施度については，「十分実施して いる」との回答が50\%を超える項目が，「電気椢 のメンテナンス助成」,「ロケット花火の助成」,

「電気柵設置の助成」の3項目となっており, 現 行対策に注目すると，特に，「駆除」に関連する 「捕獲檻の設置」，「巡回者による駆除」におい

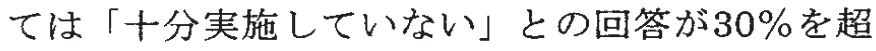
えている.

\section{3）対策毎の評価}

(1)駆除対策

次に，設問毎の評価を踏まえ，特筆すべき 3 つ の対策に注目してみていく、まず「巡回者による 駆除」についてである。「巡回者による駆除」は， 認知度は高く, 参加している（駆除を依頼してい る）農家は約 $60 \%$ となっている. 加えて有効性の 設問で「有効である」との回答が約 $82 \%$ と高くな っている。一方で，実施度については，同じく駆 除に関わる「捕獲檻の設置」と同様に，「十分実 
施していない」の割合が他の対策に比べて高くな っている.また，駆除については，アンケートに おいて設けた「鳥獣害対策についての自由回答欄」 3）において，最も記述が多く，また調查中にも駆 除に関する要望が多く寄せられた。

このような駆除に関する要望は，被害感情に影 響を受けていると考えられる4．しかし駆除は， 農家の要望通りにはならない。西目屋村では研究 者のアドバイスを受けて駆除頭数等を決めている ため，駆除実績に関する情報を農家に積極的に提 供することで,被害感情を軽減させる必要がある。 またその意味において，駆除に限らず鳥獣害対策 に関する情報を農家と共有することが，重要にな っている.

\section{(2)個人等で行っている対策}

次に個人等で行っている対策についてであるが， 「犬による追い払い」，「林に隣接するリンゴ榯 （枝）の伐採」は，認知度は低いものの，有效性 は比較的高いと評価されている。「犬による追い 払い」については，いわゆる「モンキードッグ」 活動の全国的な拡大に加え，同県のむつ市脇ノ沢 地区でも行われているため，高い数值となってい ると考えられる.また「林に隣接するリンゴ樹(枝) の伐採」については, 鳥獣害 (サル害) の権威で ある和田一雄氏が，西目屋村調査時に勧めたもの であり5，この点が影響して高い数值になってい る，と考えられる。このように，「犬による追い 払い」，「林に隣接するリンゴ樹（枝）の伐採」 は,有効性が高く評価されているにもかかわらず， 赛施されていない（実施度が低い）。寒施主体の 設問では，両項目共に「村が行うべきだ」との回 答は多くなく，「個人が行うべきだ」との回答と 同程度である，鳥獣害の特性から個人で行う対策 には限界があり，市町村が行う対策においても限 られた予算・人員では全てに対応出来るわけでは ない，どの主体がどのような対策を行うか検討が 必要である。

\section{(3)電気姗対策}

最後に「電気柵対策」に注目する。電気柵の設 置及びメンテナンスは, 村主導の対策において最 も重要視されてきた対策である。そのため, 認知 度も高く, 有効性も高い, との評価を受けている。
表 4 電気柵事業における 参加希望を有する不参加者の割合

\begin{tabular}{|c|c|c|c|c|c|c|}
\hline \multicolumn{7}{|c|}{ （単位：\%） } \\
\hline & 専㤟家 & $\begin{array}{c}\text { 第 } 1 \text { 種 } \\
\text { 兼業農家 }\end{array}$ & $\begin{array}{c}\text { 第 } 2 \text { 種 } \\
\text { 兼業農家 }\end{array}$ & 40代 & 50 代 & 60代 \\
\hline $\begin{array}{l}\text { 電気柵メ } \\
\text { ンテナン } \\
\text { ス助成 }\end{array}$ & 14.3 & 14.3 & 71.4 & 14,3 & 14.3 & 71.4 \\
\hline $\begin{array}{l}\text { 電気梱設 } \\
\text { 置助成 }\end{array}$ & 20.0 & 0.0 & 80.0 & 20.0 & 0.0 & 80.0 \\
\hline
\end{tabular}

盗料：アンケート調查より筆者が作成.

その一方で，実施度は，「十分実施している」と の回答は,「電気柵メンテナンス助成」,「電気 柵設置助成」共に, 約 $50 \%$ 程度にとどまっている。

ここで,「電気柵メンテナンス助成」,「電気柵 設置助成」の参加度, 特に「行いたいが, 行って いない」の回答者に注目する.

表 4 は，「電気柵メンテナンス助成」，「電気 柵設置助成」の 2 項目において, 参加度の設問に 「行いたいが，行っていない」と回答した人の農 家区分及び年齢構成の割合を示したものである. これをみていくと, 農家区分では兼業農家, 特に 第二種兼業農家, 年齢構成では60代以上の割合が 高い傾向にある。両対策において助成を行うのは あくまで材料費（両対策共に100\%助成）であり， 設置やメンテナンスを行う際の人件費などは，農 家の個人負担となっている。事例は限られるが, こういった農家群が電気柵に対する参加希望を持 ちながらも不参加, といらケースが考えられる。 生産性の低さから歴史的に兼業農家が多い地域で あり，高齡化も進んでいることからこれらの農 家に対して役場がどのように対応するかが重要と なる.

\section{5.おわりに}

本論文の課題は, 市町村主導による鳥獣害对策 の展開を整理し，農家アンケートより，これまで 採られた対策の評価を明らかにすることである。

青森県西目屋村は, 比較的早くから鳥獣害が確 認され，対策についても村を主導とし，比較的早 くから取り組まれてきた。これに対する農家評価 をみていくと, 現行対策については認知度が高く, 村が実施主体となって行うべきだとの評価が得ら れたものの, 参加度, 有効性, 実施度の項目につ いては評価が分かれた。 そこで特に，3つの対策 
の評価に注目した。

第一に「駆除対策」である.アンケート調查及 び自由回答欄をみていくと駆除を推奖する評価が 多く聞かれた。駆除は生態系との関連から，農家 の要望通り行うことが出来ない。そのため，農家 の被害感情を軽減させることが重要であり，駆除 などの情報を農家と共有することが必要となる。

第二に「個人等で行っている対策」である。特 に「犬による追い払い」，「林に隣接するリンゴ 樹（枝）の伐採」は，有効性が高いと評価してい るにも関わらず,対策が進んでいない.そこには， 対策の実施主体の問題があり，どの実施主体がど の対策を行うか, 議論する必要がある.

第三に，「電気相対策」である。電気棚は設置・ メンテナンスの両対策に㧤いて, 資材の無償提供 を行っているものの，設置費用の負担があること から，第二種兼業農家，高齡農家などを中心に参 加したくても参加できない農家がみられる。これ らの農家をどのように支援し，負担を軽減してい くか議論していく必要がある.

法整備などを受け，鳥獣害対策の担い手として の市町村の役割が増している。一方で，鳥獣害が 深刻化する中山間地域農業は, 多くの課題を抱え, 近年その課題は増加，深刻化している。このよう な状況を鑑み，より効果的な鳥獣害対策を行うた めには，被害農家の声を拾い上げていく必要があ ると考える。

注

1） NAPの詳細な活動については，江成・丸山[1]を参 照願いたい。

2）「巡回者による追い扎い」，「捕獲檻の設置」，「巡 回者による駆除」「「ボランティアによる追い払い」 の4対策は，いずれも個々の農家が村に依頼をして 実施される対策であることから, 参加度の設問では 「依頼している（したことがある）」，「依頼して いない（したことがない）」，「依頼したいが，依 頼していない」の3つの選択肢となる。

3）自由回答欄では，13の回答があり，内訳は「鳥獣害
対策全体について」（3件），「駆除について」（4 件），「電気柶について」（3件），「情報の提供 について」（2件），「追い払いについて」（2件）， 「その他」（2件）であった。

4）鈴木 [6] は，被害農家の被害感情が高まることで， 「駆除」対策への要望が強まる傾向があることを指 摘している. 加えて, 被害感情の複雑性から，その 可変性についても言及している.

5）和田一雄は，生態学的知見から西目屋村での鳥獣害 について調查を行っており（和田[10]），林に隣接 するリンゴ樹（枝）の伐採を提唱した. 加害動物（特 に猿）が出現しにくい環境を整備することに加えて， 電気柵の管理等にも効果がある，としている.

参考文献

[1] 江成広斗・丸山直樹「白神山地における西目屋村 アニマルパトロールの取り組みと地域社会の展望」 『ワイルドライフ・フォーラム』, 9(1-2), 2004年, pp9-18.

[2] 神崎伸夫・見宮歩・丸山直樹「山梨買におけるイ ノシシ, サルによる農作物被害の実態と農家の意識」 『野生生物保護』，8(2)，2003 年, pp.1-9.

[3] 室山泰之『里のサルとつきあうには一野生動物の 被害管理』京都大学出版会, 2003 年.

[4] 農林水産省生産局農業生産支援課鳥獣被害対策 室『全国の野生鳥獣類による農作物被害状況につい て』, 2004-2008 年.

[5]野津覄「被害防止の法はどう変わったか 鳥獣被 害防止特措法の成立」『農業と経済』，75(2)，2009 年, $\mathrm{pp} .30-34$.

[6]鈴木克哉「野生動物との㜞軪はどのように解消で きるか?一地域住民の被害認識と獣害の問題化プ 口セス一1『環境社会学研究』, 14, 2008 年, pp.55-68.

[7] 竹鼻悦子・神崎伸夫「島根県のイノシシによる農 作物被害, その対策の実態と農業の展望」『野生生 物保護』, $9(1), 2004$ 年, pp.23-45. 野津喬「被害 防止の法はどう変わったか 鳥獣被害防止特措法 の成立」『農業之経済』, 75(2), 2009 年, pp.30-34.

[8]鳥獣による農林水産業被害対策に関する検討会 『鳥獣による農林水産業被害対策に関する検討会 報告書』農林水産省生産局農業生産支援課鳥獣被害 対策室, 2005 年.

[9] 和田一雄『ニホンザル保全学一猿害の根本的解決 に向けて一』農山漁村文化協会, 2008 年.

[10] 和田一雄・今井一郎「青森県西目屋村の猿害に ついて」『野生生物保護』, 7(2), 2002 年, pp.99-110.

〔2011 年 3 月 30 日受理〕 